\title{
Simulation of Mach-Effect Illusion Using Three-Layered Retinal Cell Model and Monte Carlo Method
}

\author{
Akinori Ueno Member (Tokyo Denki University, ueno@eee.dendai.ac.jp) \\ Ken Arai Non-member (Tokyo Denki University) \\ Osamu Miyashita Member (Tokyo Denki University)
}

Keywords : physiome, lateral inhabitation, perceptive field, mach bands

It is known that human vision system mis-perceives the grey scale profile of an image in Fig.1(a), which is cubic diagram in Fig.1(b), as for that in Fig.1(c). This optical illusion emphasizing edges of the object is called Mach-effect. We proposed a novel retinal model capable of simulating the Mach-effect. The model was composed of a rod cell layer, a bipolar cell layer, and a ganglion cell layer as shown in Fig.2, according to anatomical structure of the retina. Lateral inhibition network and perceptive field network were introduced between the layers, respectively. Photoelectric conversion at a rod cell for a single photon incidence was defined as equation (1), and the outputs of the rod cell $\left(v_{r o d}\right)$, the bipolar cell $\left(v_{\text {bpl }}\right)$, and the ganglion cell $\left(v_{\text {gngl }}\right)$ were calculated using equation (2) (5).

$$
\begin{aligned}
& v_{\text {phot }}(t)=A t \cdot \exp (-K t)+B \\
& v_{\text {rod }}(\Delta t \cdot N)=\sum_{n=1}^{N} \gamma_{n} \cdot v_{\text {phot }}(\Delta t \cdot(N-n))
\end{aligned}
$$

where

$$
\gamma_{n}= \begin{cases}1, & \text { if transmitted } \\ 0, & \text { otherwise }\end{cases}
$$

$$
\begin{aligned}
& v_{b p l}(t)_{i j}=\frac{1}{N_{2}}\left(\sum_{i=i-\frac{n-1}{2}}^{i+\frac{n-1}{2}} \sum_{j=j-\frac{n-1}{2}}^{j+\frac{n-1}{2}}(\alpha+1) \cdot v_{r o d}(t)_{i j}\right. \\
& \left.-\sum_{i=i-\frac{N-1}{2}}^{i+\frac{N-1}{2}} \sum_{j=j-\frac{N-1}{2}}^{j+\frac{N-1}{2}} v_{r o d}(t)_{i j}\right) \\
& v_{g n g l}(t)_{i j}=\frac{1}{N^{2}} \sum_{i=i-\frac{N-1}{2}}^{i+\frac{N-1}{2}} \sum_{j=j-\frac{N-1}{2}}^{j+\frac{N-1}{2}} v_{b p l}(t)_{i j}
\end{aligned}
$$

Also the input impage to the model was simulated as a distribution of the number of transmitted photons through the input image by Monte Carlo method. Since this model successfully simulated not only Mach-effect illusion (see Fig.3), but also DOG-like (Difference of Gaussian like) profile for a spot light incidence, the model was considered to form functionally the perceptive field of the retinal ganglion cell.

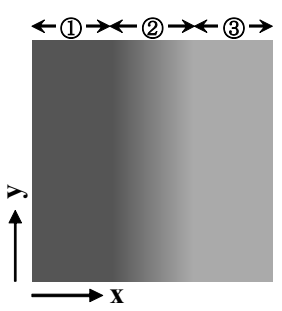

(a) A typical image

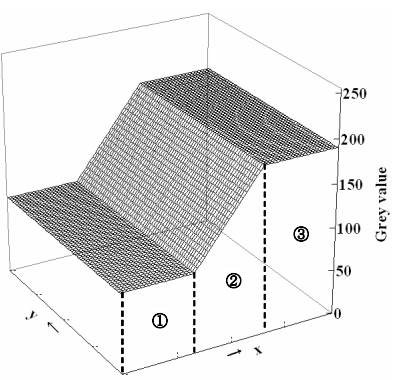

(b) Grey scale profile of (a)

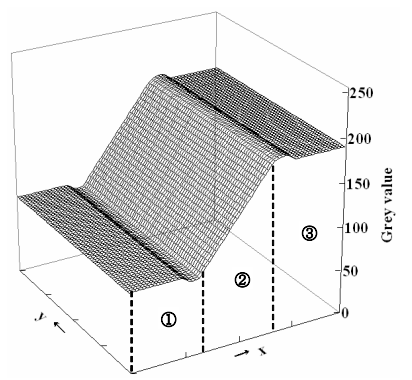

(c) Typical perception profile in grey scale

Fig. 1. Explanation of Mach-effect illusion. (a) A typical image which induces Mach-effect illusion, (b) grey scale profile of the image (a), and (c) the typical perception profile in grey scale

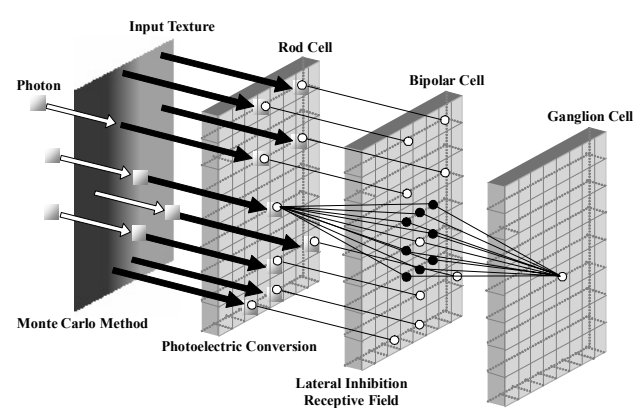

Fig. 2. Schematic of input layer and the three-layered retinal cell model

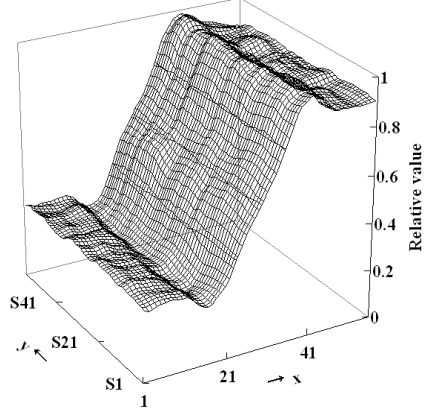

Fig. 3. Typical result of the model for $4 \mathrm{kHz} /$ pixel incidences of photons to the image in Fig.1(a) 


\title{
三層網膜細胞モデルとモンテカルロ法による マッハ効果錯視の模擬
}

\author{
正 員 植野 彰規*广 非会員 新井 研* \\ 正員宮下收*广
}

\section{Simulation of Mach-Effect Illusion Using Three-Layered Retinal Cell Model and Monte Carlo Method Akinori Ueno*, Member, Ken Arai*, Non-member, Osamu Miyashita*, Member}

\begin{abstract}
We proposed a novel retinal model capable of simulating Mach-effect, which is known as an optical illusion emphasizing edges of an object. The model was constructed by a rod cell layer, a bipolar cell layer, and a ganglion cell layer. Lateral inhibition and perceptive field networks were introduced between the layers, respectively. Photoelectric conversion for a single photon incidence at each rod cell was defined as an equation, and the input to the model was simulated as a distribution of transmitted photons through the input image for consecutive incidences by Monte Carlo method. Since this model successfully simulated not only Mach-effect illusion, but also DOG-like (Difference of Gaussian like) profile for a spot light incidence, the model was considered to form functionally the perceptive field of the retinal ganglion cell.
\end{abstract}

キーワード：フィジオーム，側抑制，受容野，マッハバンド

Keywords : physiome, lateral inhabitation, perceptive field, mach bands

\section{1. はじめに}

脳や神経系の複雑な機能，仕組みを理解するためには， 解明された細胞，神経の電気的な応答といった生体機能の 個々の知見を何らかの形で統合し，システムとして捉えて いく必要がある。このような脳・神経科学と情報科学を統 合する新しい研究領域はフィジオームもしくはニューロイ ンフォマティクスと呼ばれており(1)(2), 現在, 各種の生体情 報処理のモデル化や統合, そのためのデータベースの構築 など, 様々な研究が行われている。中でも視覚系のモデル 化は，視覚障害者のための人工眼や人工網膜の実現のため に有用であることから，基礎科学の視点のみならず，工学 的な観点からも研究の必要性がうたわれている。

ヒト視覚系の研究では, 入力に関しては定量的に計測（設 定）できるが，出力（視知覚）応答を定量的に得ることが 困難であるため，モデルの妥当性の検証に各種錯視現象が 用いられてきた。本論文で注目するマッハ効果も, 明るさ 知覚に関連する錯視である。明るさ知覚のモデルでマッハ 効果錯視を説明したものとしては Ratliff ${ }^{(3)(4)}$ のモデルが代表

\footnotetext{
* 東京電機大学大学院理工学研究科電子情報工学専攻 干350-0394 埼玉県比企郡鳩山町石坂 Graduate School of Science and Engineering, Tokyo Denki University

Ishizaka, Hatoyama-machi, Hiki-gun, Saitama 350-0394

$\dagger 2007$ 年 4 月より, 東京電機大学工学部電気電子工学科
}

的である。このモデルではカブトガニや脊椎動物の網膜で 観測される側抑制回路を導入し, 模擬に成功している。ま た，基礎科学的な観点からはモデルが視覚系全体を統一的 に説明できることが望ましく, Ratliff のモデルに続いて，例 えばBurr $ら^{(5)(6)}$, 本郷ら ${ }^{(7)}$, 塚田ら ${ }^{(8)}$ が他のモデルを提案し ており,より詳細なマッ八効果錯視を, または複数の錯視 を模擬することに成功している。

一方，各階層における機能のモジュール化と統合を目指 すフィジオーム的視点, ならびに人工網膜等への応用を意 識した工学的視点に立つと, 網膜モデルにおいては網膜ま での情報処理を模擬するにとどめる必要がある。錯視現象 が視覚系のどの層で生じたのかを議論することは通常困難 であるが，マッ八効果錯視に関して言えば，前述のように 網膜で生理学的に観測された側抑制によりある程度説明で きる可能性があることから，本論文では「マッ八効果錯視 の主要現象は網膜での情報処理の結果生じる」との仮説を たて, 網膜モデルのみによりマッハ効果錯視を模擬するこ とを目的とした。ただし, Ratliffのモデルを始めとするこれ までの明るさ知覚のモデルの多くは，アナログ的な式表現 に基づくモデルであったため, 式表現が難しいパターンを 入力とすることができなかった。また, 静的な錯視現象の 説明を主眼としていたことから, 動画像を入力することが できず拡張性の点で十分とは言えない。そこで, 本論文で 
は入力部を「画像の濃淡值に応じた光子の透過数分布の時 間的変動」として表現し，かつ，初段の網膜細胞（かん体 細胞）層に光子 1 つに対する受光時間応答を導入すること で, 動画像の入力を可能とした。なお, モデルの構築にあ たっては, フィジオーム的なアプローチを意識し, 解剖学 的な構造や電気生理学的反応をできるだけ反映することを 心がけた。また，マッハ効果はステップパターンに対して 消失することが報告されているが(9)(10), この現象を説明する ために他のモデルに導入された線検出器 ${ }^{(7)(10)}$ や棒検出器 ${ }^{(10)}$, または特徴抽出部 ${ }^{(8)}$ は, 網膜よりも高次な領域に存在する可 能性が高いことから, 提案モデルではマッ八効果の消失に ついては模擬の対象から外した。

\section{2. マッハ効果錯視}

マッ八効果は錯視の一種であり，物体の輪郭を強調する 視覚的効果である ${ }^{(11)}$ 。図 1(a)はマッ八効果が知覚される画像 の一例である。図1(a)の画像は, 図中の1)〜 (3)で表示した 3 つの画像領域から構成されており，濃淡值を縦軸として 3 次元表示すると図 1(b)のよう表される。つまり, 左右の領域 (1), (3)の濃淡值は一定, 領域(2)の濃淡值は(1)と（3)の值を線 形に補間した值となっている。しかしながら，我々人間の
目には，領域(1)と(2)の境界付近に黒い縦線が，また領域(2) と (3)の境界付近には白い縦線が知覚される。この錯視によ って知覚される濃淡值を 3 次元表示すると, 図 1(c)のような ることが報告されている(12)。

\section{3. 三層網膜細胞モデルと光受容応答の模擬}

網膜での情報処理を模擬するため, 解剖学的知見に基づ き(11), かん体細胞層, 双極細胞層, 神経節細胞層の三層か らなる網膜細胞モデルを構築した。また, 光子 1 つがかん 体細胞に入射した時の光受容応答を, 文献 ${ }^{(13) \sim(15)}$ を参考に し, 定式化（近似）した。さらに, 生理学的な知見として 知られている受容野をモデル内に形成するため, 層間に側 抑制構造をもつネットワークを導入した ${ }^{(16)}$ 。錯視を生じさ せる画像を網膜への入力に変換するため, モンテカルロ法 を用いて画像背面から光子を発生させ, 画像の濃淡值に応 じて透過率を変化させ, 網膜 (かん体細胞) に入力する光 子数を確率的に決定した。下記に詳細を記述する。

〈3·1〉 モンテカルロ法による光強度分布の生成 ま ず, モデルへの入力画像を $64 \times 64$ pixel の濃淡画像として準 備した。網膜に入射する光の強度分布を，入力画像のパタ ーンに応じて変えるため, 画像の各画素の背面から光子 1

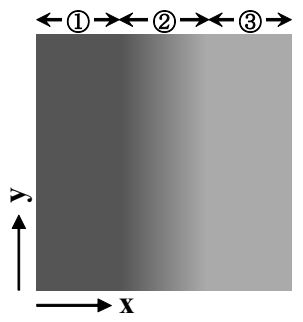

(a) A typical image

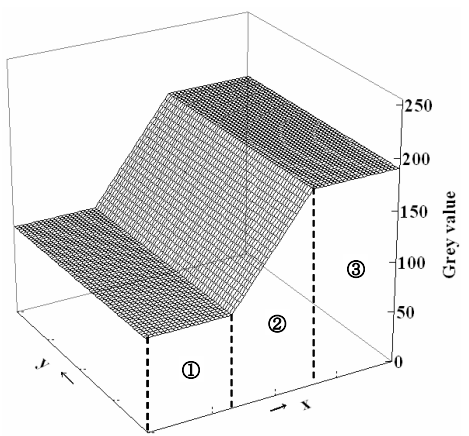

(b) Grey scale profile of (a)

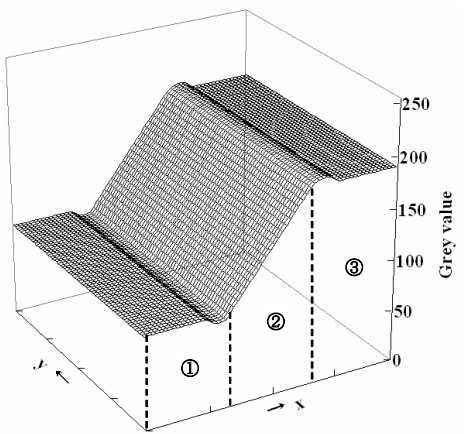

(c) Typical perception profile in grey scale

図 1 マッ八効果錯視の説明（(a) マッ八効果錯視を生じる典型的な画像，（b) その 3 次元濃淡グラフ,

(c) 知覚される濃淡值の概形)

Fig. 1. Explanation of Mach-effect illusion. (a) A typical image which induces Mach-effect illusion, (b) grey scale profile of the image (a), and (c) the typical perception profile in grey scale.

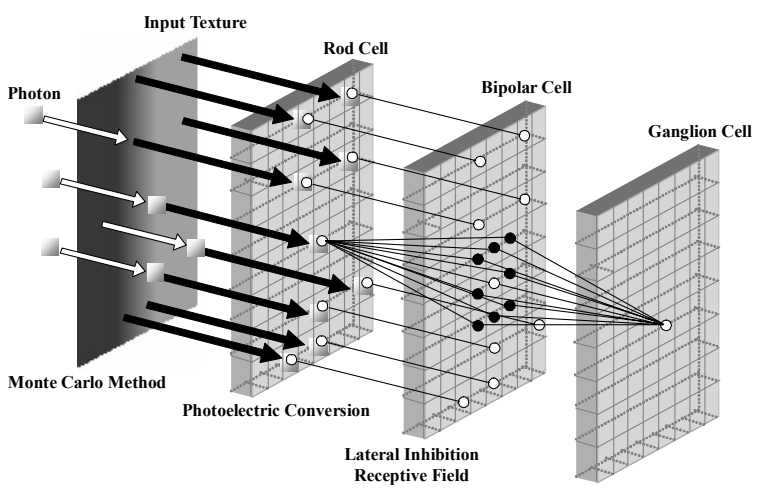

(a) Input layer and the three-layered retinal cells model

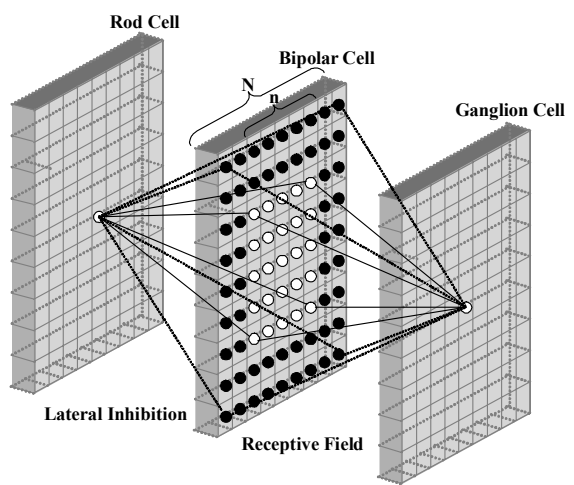

(b) Structure of networks between the layers

図 2 構築した三層網膜細胞モデルに画像入力層を加えた図(a), および層間ネットワークの構造(b)

Fig. 2. Schematics of (a) input layer and the three-layered retinal cell model, and (b) structure of networks between the layers. 
つを同時に発生させ，一定の時間間隔で発生を繰り返した。 発生した光子は図 2(a)左側の図のように直進し各画素に入 射されるが，画素を透過するか否かはモンテカルロ法によ り乱数を用いて確率的に決定した。透過率は画素の濃淡值 （0２55）に比例させ, 濃淡值 0 （黒）で $0 \%$, 濃淡值 255 (白) で100\%になるように設定した。

〈3·2〉 三層網膜細胞モデル 光が眼球に入射する と, 網膜の視細胞であるかん体細胞と錐体細胞が光を受容 する。錐体細胞は色視に関与していると言われており，本 研究では色情報のない画像を入力として取り扱うことか ら, 光強度に応答するかん体細胞にの夕注目した。かん体 細胞の出力は, 双極細胞, 次いで神経節細胞へと伝達され ることから, 本研究では図 2(a)に示す三層のモデルを構築し た。入力画像の各画素と, 各層の細胞とを対応させるため, 各層の細胞配置も $64 \times 64$ の格子状とした。また，各層の間 にはネットワークを形成した。ネットワークの構造につい ては後述する。

〈3·3〉 仙体細胞の光受容応答 過去の動物実験よ り, かん体にインパルス的な光を照射した場合の光受容応 答の概形が分かっている ${ }^{(13) \sim(15)}$ 。これらの知見を基に, 類似 した応答を模擬するため, 本研究では光子 1 つに対する光 受容応答 $\boldsymbol{v}_{\text {phot }}$ を( 1)式のように近似した。

$$
v_{\text {phot }}(t)=A t \cdot \exp (-K t)+B
$$

ここで， $t$ は時間， $A, K, B$ はそれぞれ定数である。本モデ ルでは $A=7.0 \times 10^{-12}, B=-35.0 \times 10^{-9}, K=20$ とした。また，時 刻 $t=\Delta t \cdot N$ ( $\Delta t$ は光子の発生間隔) におけるかん体細胞の出 力電圧 $v_{\text {rod }}$ は，時刻 0 から $t$ の間に入射した各光子に対する 時刻 $t$ での応答の総和とし, $(2)$ 式により算出した。

$$
v_{\text {rod }}(\Delta t \cdot N)=\sum_{n=1}^{N} \gamma_{n} \cdot v_{\text {phot }}(\Delta t \cdot(N-n))
$$

ただし，

$$
\gamma_{n}= \begin{cases}1, & \text { if } \text { transmitted } \\ 0, & \text { otherwise }\end{cases}
$$

である。(1), (2), ( 3 )式より算出した, かん体細胞の応 答例を図 3 に示す。図3(a) は光子 1 つに対する応答であるが, 照射後 $0.05 \mathrm{~s}$ 付近でピーク值をとり, $0.4 \mathrm{~s}$ 程度で応答がほぼ 消失する。また， $4 \mathrm{kHz}, 0.05 \mathrm{~s}$ 間の照射では (図 3(b)参照), かん体の応答形状は図 3(a) とほとんど变わらないが, 透過率 に応じてピークに変化が認められる。更に，4kHz，0.5s 間 の照射では, かん体の応答が照射後 $0.2 \mathrm{~s}$ から $0.3 \mathrm{~s}$ で定常状 態に達し, 透過率に比例した定常值を示すことが確認でき る。なお, 定常值に見られる摇らぎは, 光子の透過を確率 的に決定しているため, 透過光子数にバラツキが存在する ためである。

〈3.4〉側抑制・受容野ネットワーク 生物の感覚神 経系には, 近くに存在するニューロン同士が互いに相手側 の反応を抑制しあう現象が多数存在し，これを側抑制と呼 んでいる(11)。提案モデルにおいて側抑制を実現するため, かん体細胞と双極細胞間に図 2(b)左側のようなネットワー クを形成した。このネットワークは，1つのかん体細胞から 複数 $(N \times N$ 個, $N$ は奇数 $)$ の双極細胞に結合が形成されて いる。また, 白丸で示した中央部 $(n \times n$ 個, $n$ は奇数 $)$ の 双極細胞へは興奮性（伝達係数 $\alpha$ が正）の, 黒丸で示した 周辺部（ $N \times N$ から $n \times n$ を引いた領域）の細胞へは抑制性 (伝達係数がー1）の結合を構成した。このような側抑制構 造ネットワークを, 全てのかん体細胞について形成した。 格子状の左から $i$ 番目, 下から $j$ 番目にあたる双極細胞の出 力 $v_{b p l}(\mathrm{t})_{i j}$ は( 4 )式のように定義した。

$$
\begin{aligned}
& v_{b p l}(t)_{i j}=\frac{1}{N^{2}}\left(\sum_{i=i-\frac{n-1}{2}}^{i+\frac{n-1}{2}} \sum_{j=j-\frac{n-1}{2}}^{j+\frac{n-1}{2}}(\alpha+1) \cdot v_{r o d}(t)_{i j}\right. \\
& \left.-\sum_{i=i-\frac{N-1}{2}}^{i+\frac{N-1}{2}} \sum_{j=j-\frac{N-1}{2}}^{j+\frac{N-1}{2}} v_{r o d}(t)_{i j}\right)
\end{aligned}
$$

双極細胞と神経節細胞閒の結合については, 図 2(b)右側の ようなネットワークを構築した。網膜においては, 1 つの神 経節細胞対して影響を及ぼしうるかん体細胞が複数あり, この細胞を実験に基づき 2 次元的に記録したものを受容野

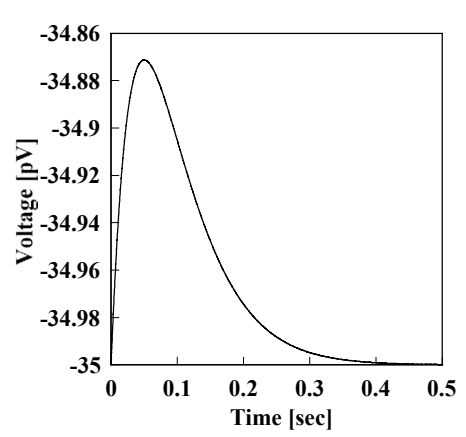

(a) To a single photon

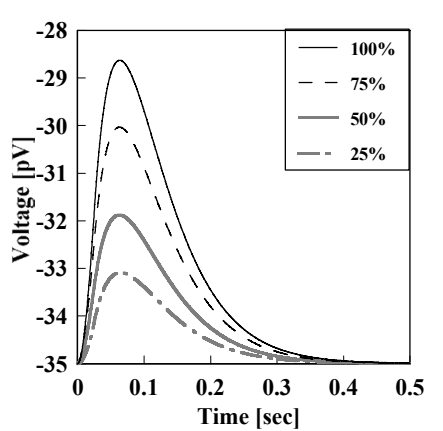

(b) To $0.05 \mathrm{~s}$ incidence at $4 \mathrm{kHz}$ through a texture with various optical transmittances

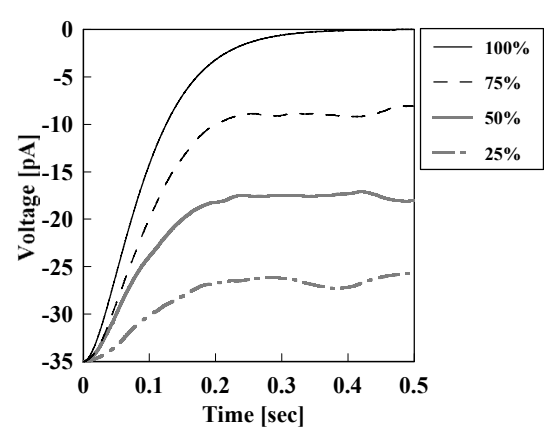

(c) To $0.5 \mathrm{~s}$ incidence at $4 \mathrm{kHz}$ through a texture with various optical transmittances

図 3 かん体細胞モデルにおける光受容応答（(a) 単一光子を受光した場合，(b) 光子を $4 \mathrm{kHz}$ で $0.05 \mathrm{~s}$ 間受光した場合，

(c) 光子を $4 \mathrm{kHz}$ で $0.5 \mathrm{~s}$ 閒受光した場合)

Fig. 3. Photoreceptive responses of a modeled rod cell (a) to a single photon, (b) to $0.05 \mathrm{~s}$ incidence at $4 \mathrm{kHz}$ through an input image with various optical transmittances, and (c) to $0.5 \mathrm{~s}$ incidence at $4 \mathrm{kHz}$ through an input image with various optical transmittances. 
と呼んでいる。また，神経節細胞に対する影響の与え方に は，興奮性のもの（ON 反応）と抑制性のもの（OFF 反応） の 2 種類が存在する。過去の生理学的知見より, 神経節細 胞の受容野は円形で, 中央領域が ON 反応を示し, 周辺領域 が OFF 反応を示すことが知られている ${ }^{(11)(16)}$ 。側抑制ネット ワークの導入により, かん体細胞 1 つに光が入射されると, 双極細胞上には中央領域に ON, 周辺領域に OFF の応答が えられることから，図 2(b)右側のように，側抑制ネットワー クで結合した $N \times N$ の領域全体を $1 つ の$ 神経節細胞に再結合 することにより, ON 中心 OFF 周辺の受容野を実現するこ とが可能である。そこで，このような受容野ネットワーク を全ての神経節細胞について形成し, 各神経節細胞の出力 $\boldsymbol{v}_{\text {gngl }}(\mathbf{t})_{i j}$ を( 5 )式のように定義した。

$$
v_{\text {gngl }}(t)_{i j}=\frac{1}{N^{2}} \sum_{i=i-\frac{N-1}{2}}^{i+\frac{N-1}{2}} \sum_{j=j-\frac{N-1}{2}}^{j+\frac{N-1}{2}} v_{b p l}(t)_{i j}
$$

\section{4. シミュレーションおよび結果}

構築したモデルに対して図1(a)を入力画像として, シミュ
レーションを行った。結果を図 4 に示す。結合係数は $\alpha=2.5$, 側抑制・受容野ネットワークのサイズは $N=9, n=5$ とした。 図 4(a)は 1 画素あたりに光子を 255 個発生させたときに, か ん体に入射した光子数の結果例である。結果より, 入力画 像の濃淡值と同様な光子数パターンが得られている。した がって, 入力画像の濃淡值に応じて光子の透過率を決定す ることで, モンテカルロ法により入力画像と同様な入射光 強度パターンを模擬できることが確認できた。

次に，光子の発生を $4 \mathrm{kHz}, 0.5 \mathrm{~s}$ 間として同様のシミュレ ーションを行った。各細胞層の出力図 4(b)〜(c)を見ると， かん体細胞層（図 4(b)）では図 4(a) と同様に, 入力画像の濃 淡值と類似した, 出力電圧分布が得られた。図4(a)よりもバ ラツキが少ないのは, 入射光子数が図 4(a)の時よりも多かっ た（計 2000 個）ためである。一方, 図 4(c)の双極細胞層で は，側抑制ネットワークの影響により領域(1)と (2), (2) と (3) の境界付近において, 輪郭が強調されている。また, 神経 節細胞層では, 双極細胞層の出力が平滑化され, 輪郭強調 の特徵は残されたまま, なめらかな特性が得られている。 得られた特性は，これまで報告されたマッハ効果錯視の特

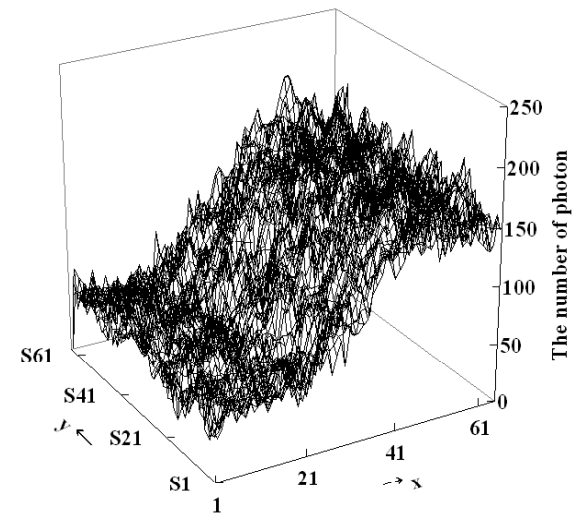

(a) Transmission through the image for 255 photon incidences

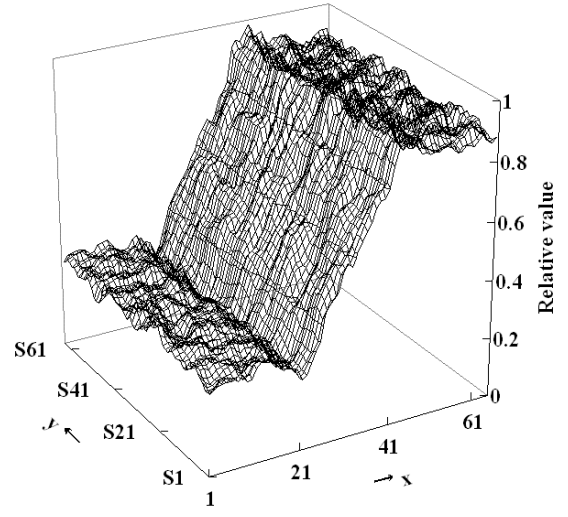

(c) Bipolar cell layer

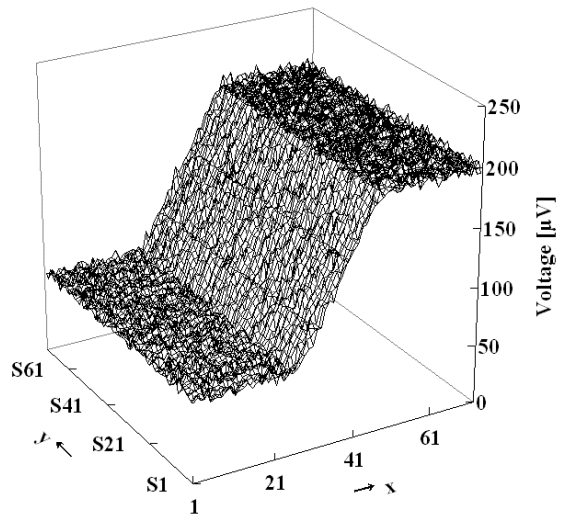

(b) Rod cell layer

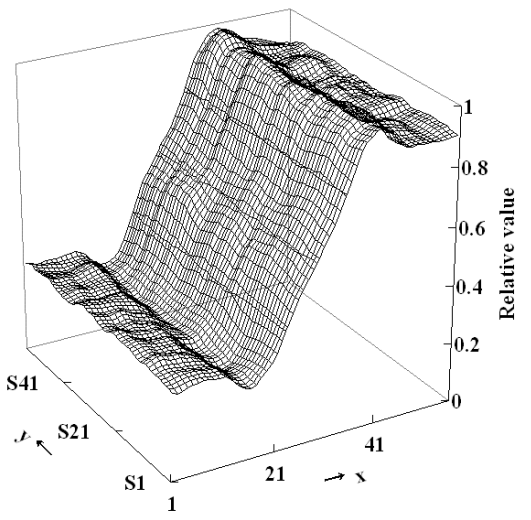

(d) Ganglion cell layer

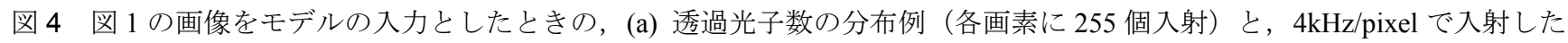
ときの $0.5 \mathrm{~s}$ 後における, (b) かん体層の応答例, (c) 双極細胞層の応答例, (d) 神経節細胞層の応答例

Fig. 4. Typical results of the model for the incidences of photons to the image in Fig.1(a). (a) is a distribution of transmission number of photon after 255 incidences/pixel. (b) is a response of the rode cell layer, (c) is a response of the bipolar cell layer, and (d) is a response of the ganglion cell layer for $4 \mathrm{kHz} /$ pixel photon incidences. 
徵をよく捉えていることから，構築したモデルにより，マ ッハ効果錯視を模擬できたと言える。

\section{5. 検 討}

図 4 の結果より, 構築したモデルを用いてマッハ効果錯 視を模擬できることが示された。一方, 過去の知見より, スポット光を照射した際の神経節細胞の応答は，ガウス関 数の差である DOG 関数（difference of gaussian）で近似でき ることが知られている(17)(18)。そこで入力画像を図 1(a)から 図 5(a)に変更し，スポット光照射を模擬した。なお，他の条 件は固定のままとした。結果を図 5(b)〜 (d)に示す。図 5(d) の出力を見ると, DOG 関数様の出力が得られており, 生理 学的知見と一致することが確認できた。ここで図 5(d)の周辺 部のくぼみは側抑制の影響によるもので, 生理学データに おいても同様なくぼみが観測されている。Marr \& Hildreth ${ }^{(19)}$ によると X 型 (持続型) 神経節細胞の受容野は $\nabla^{2} G$ (Laplacian of Gaussian) で近似できることから, 生理学的に 観測される波形は網膜像である図 5(b)をガウス関数でぼか した (ガウス関数との畳み込み積分) 後, 2 次微分した波形
に等しい。一方, 提案モデルでは, 図 2 および(4), ( 5 )式 より,まず図 5(b)に対してラプラシアンオペレータとの畳み 込み（2 次微分）を行い, その後, 平滑化の曽み込みを行っ ている。 $\nabla^{2} G$ も提案モデルも 2 次微分と平滑化を組み合わ せているという点で共通であり, その結果, 両者が同様な 出力となったものと考えられる。したがって, 提案モデル はフィジオーム的アプローチによる網膜生理モデルである が, 計算論的観点からみた網膜情報処理モデルとも矛盾の 少ないものとなっている。なお, 本論文では, モデルを単 純化するため導入しなかったが, 神経節細胞には Y 型（過 渡型）神経節細胞も存在する。 $\mathrm{Y}$ 型細胞では受容野中心の 入力と周辺からの入力が非線形に加算されていることが示 唆されており ${ }^{(18)(20)}$, 計算論的には Laplacian of Gaussian の時 間微分で近似されることが知られている(18)(21)。 Barlow \& Quarles $^{(22)}$ は, カブトガニのモデル（理論）と生理学データ との比較研究において, 非線形成分がマッ八効果の振幅と 関与していることを示していることから, 今後は, 詳細な モデル構築を目指して, Y 型細胞の組み込みも視野に入れ る必要がある。

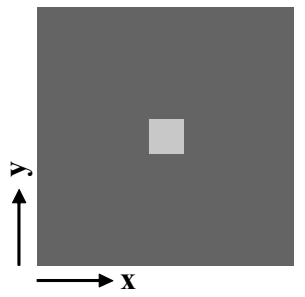

(a) An input image for spot incidences

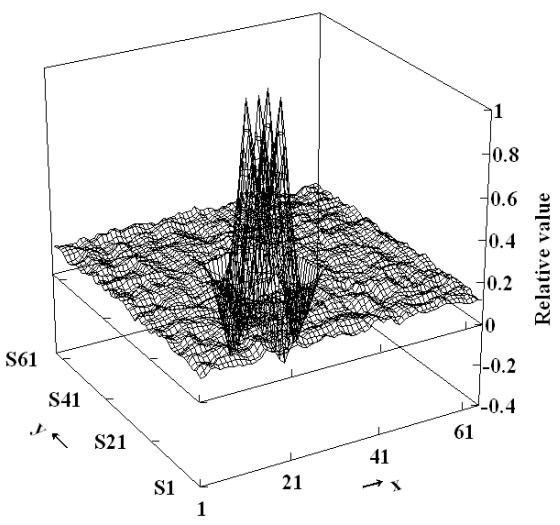

(c) Bipolar cell layer

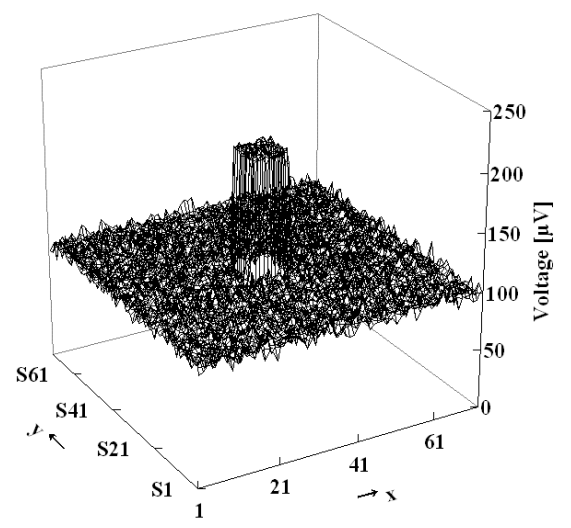

(b) Rod cell layer

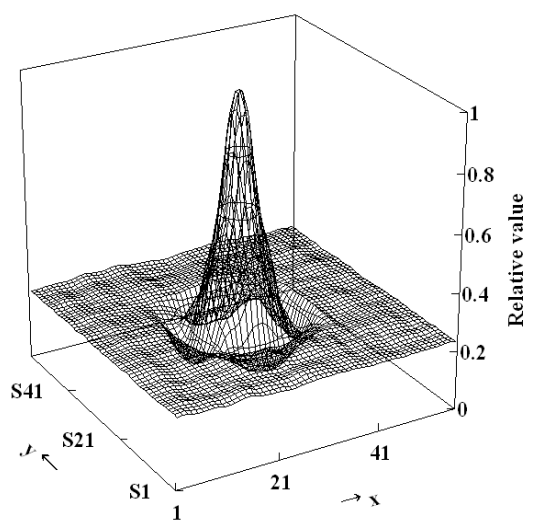

(d) Ganglion cell layer

図 5 スポット光照射用の入力画像と $4 \mathrm{kHz} / \mathrm{pixel}$ のスポット光入射に対する $0.5 \mathrm{~s}$ 後のモデルの応答例（(a) 入力画像， (b) かん体細胞層の応答, (c) 双極細胞層の応答, (d) 神経節細胞層の応答)

Fig. 5. An input image and typical responses of the retinal cell model after $0.5 \mathrm{~s}$ for spot light incidences. (a) Input image, and response of (b) rod cell layer, (c) bipolar cell layer, and (d) ganglion cell layer for $4 \mathrm{kHz} /$ pixel photon incidences. 


\section{6. まとめ}

解剖学および生理学的知見に基づき，三層からなる網膜 細胞モデルを構築し，層間に側抑制・受容野ネットワーク を導入した。モンテカルロ法により, マッハ効果錯視を生 じる典型画像を入力し, 光受容応答を模擬した結果, マッ 八効果錯視とよく似た出力を得ることに成功した。提案モ デルはスポット光照射時における DOG 関数様の出力も模擬 できたことから, 生理学的知見および計算論的な網膜情報 処理と矛盾の少ない神経節細胞の受容野を形成できている と考えられる。本モデルは従来のモデルと比較して以下の 特長を有している：(1)細胞の階層構造が明確で生理学デー タとの比較が容易である, (2)時間変化するパターンの入力 および出力の時間応答の観測が可能である，(3)入力を濃淡 值パターンとして行え, 定式化の必要がなく, 入れ替えも 容易である。したがって, 提案モデルはフィジオーム的ア プローチによる網膜情報処理モデルとして有用性と発展性 が期待できる。

今後は, 本モデルの特長を生かせるよう, 網膜レベルで 生じていると推察される動的な錯視現象を調査し, その再 現を試みるとともに，解剖学的知見・生理学的知見とも照 らし合わせ, より詳細で生体に近いモデルを構築すること が課題である。また，本モデルでは加味しなかった，錐体 細胞や水平細胞，アマクリン細胞等もモデルに組み込み, 動的かつ色覚を伴う錯視について，モデルによる模擬を試 みたい。

(平成 19 年 1 月 24 日受付, 平成 19 年 7 月 18 日再受付)

\section{文献}

(1) 梶谷文彦・佐藤俊輔：「フィジオームと BME：ポストゲノム時代の 展望」, BME, Vol.16, No.1, pp.2-6(2002)

(2) S. Usui : "Visiome: Neuroinformatics Rresearch in Vision Project", Neural Networks, Vol.16, pp.1293-1300 (2003)

(3) F. Ratliff: "Mach Bands: Quantitative Studies on Neural Networks in the Retina", Holden-Day (1965)

(4) F. Ratliff : "Contour and Contrast", Scientific American, Vol.226, pp.90-101 (1972)

( 5 ) D. C. Burr, M. C. Morrone, and D. Spinnelli : "Evidence for Edge and Bar Detectors in Human Vision", Vision Res., Vol.29, pp.419-431 (1989)

(6) J. Ross, M. C. Morrone, and D. C. Burr : "The Conditions under which Mach Bands are Visible”, Vision Res., Vol.29, pp.699-715 (1989)

( 7 ) S. Hongo, T. Inui, and M. Kawato : "A Computational Theory and a Neural Network Model on the Brightness Perception -A Markov Random Model for the Filling-in Process", IEICE Trans. Inf. Syst. PT.2, Vol.J75-D-II, No.11, pp.1959-1967 (1992-11) (in Japanese) 本郷節之・乾 敏郎・川人光男:「明るさ知覚の計算理論と神経回路 モデルー充てん過程のマルコフ確率場モデル」, 信学論 D-II, J75-D-II, 11, pp.1959-1967 (1992-11)

(8) A. Tsukada, K. Sasaki, and H. Yagi : "A Feature Extracting Model on Brightness Perception with Lateral Inhibition”, IEICE Trans. Inf. Syst. PT.2, Vol.J77-D-II, No.4, pp.866-873 (1994-4) (in Japanese) 塚田章・佐々木和男, 八木 寛: 「側抑制を用いた知覚の特徵抽出 モデル」，信学論 D-II, J77-D-II, 4, pp.866-873 (1994-4)

( 9 ) J. Ross, J. J. Holt, and J. R. Johnstone : "High Frequency Limitation on Mach Bands", Vision Res., Vol.21, pp.1165-1167 (1981)

(10) F. Ratliff : "Why Mach Bands are not Seen at the Edges of a Step", Vision Res., Vol.24, No.24, pp.163-166 (1984)
(11) 福島邦彦:「視覚の生理とバイオニクス」, 電子情報通信学会, pp.54-69 (1976)

(12) E. M. Lowry and J. J. DePalma : "Sine-Wave Response of the Visual System. I. The Mach Phenomenon", J. Opt. Soc. Amer, Vol.51, No.7, pp.740-746 (1961-6)

(13) D. A. Baylor, G. Matthews, and B. J. Nunn : "Location and Function of Voltage-Sensitivity Conductances in Retinal Rod of the Salamander, Ambystoma Tigrinum", J. Physiol., Vol.354, pp.203-223 (1984)

(14) D. A. Baylor : "Photoreceptor Signals and Vision. Proctor Lecture", Invest. Ophthal. Vis. Sci., Vol.28, No.1, pp.34-49 (1987-1)

(15) T. Ogura, Y. Kamiyama, and S. Usui : "Ionic Current Model of the Retinal Photoreceptor and Simulation Analysis of the Photoresponse", IEICE Trans. Info. Syst. PT.2, Vol.J78-D-II, No.10, pp.1512-1521 (1995-10) (in Japanese)

小椋俊彦・神山斉己・臼井支朗 :「網膜視細胞のイオン電流モデルと 光応答のシミュレーション解析」, 信学論 D-II, J78-D-II, 10, pp.1512-1521 (1995-10)

(16) 福田 淳 - 佐藤宏道 :「脳と視覚」, 共立出版, pp.48-72 (2002)

(17) G. Osterberg : "Topography of the layer of rods and cones in the human retina”, Acta Ophthalmologica Supplementum, Vol.6, pp.1-102 (1935)

（18）乾 敏郎：「視覚情報処理の基礎」, サイエンス社, p.20-47 (1990)

(19) D. Marr and E. Hildreth : "Theory of Edge Detection", Proc. The Royal Society of London, Vol.B-207, pp.187-217 (1980)

(20) C. Enroth-Cugell and J. G. Robson : "The Contrast Sensitivity of Retinal Ganglion Cells of the Cat", J. Physiol., Vol.187, pp.517-552 (1966)

(21) D. Marr and S. Ullman : "Directional selectivity and its use in early visual processing", Philosophical Transactions of the Royal Society of London, Vol.B-275, pp.483-524 (1981)

(22) R. B. Barlow Jr. and D. A. Quarles Jr. : "Mach Bands in the Lateral Eye of Limulus -Comparison of Theory and Experiment", J. Gen. Physiol., Vol.65, pp.709-730 (1975)

植 野 彰 規 (正員) 1971 年 5 月 31 日生。1994 年 3 月慶

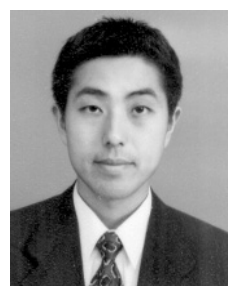
應義塾大学理工学部電気工学科卒業。1996 年 3 月同大学大学院理工学研究科生体医工学専攻 修士課程修了。1999 年 3 月同専攻博士課程修 了。博士 (工学)。同年 4 月東京電機大学理工 学部電子情報工学科助手, 2000 年講師, 2004 年助教授を経て 2007 年 4 月より同工学部電気 電子工学科准教授。生体情報計測に基づくイン テリジェントインタフェースの構築に関する研究に従事。IEEE, 電 子情報通信学会, 計測自動制御学会, 日本生体医工学会, 各会員。

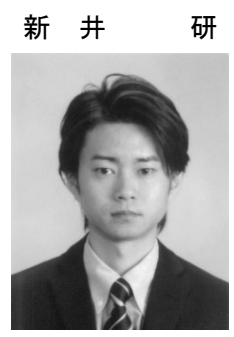

（非会員） 1977 年 3 月 27 日生。 2001 年 3 月東 京電機大学理工学部応用電子工学科卒業。2003 年 3 月同大学大学院理工学研究科応用電子工学 専攻修士課程修了。現在, 日本光電工業株式会 社勤務。在学中, マッ八効果錯視のシミュレー ションに関する研究に従事。

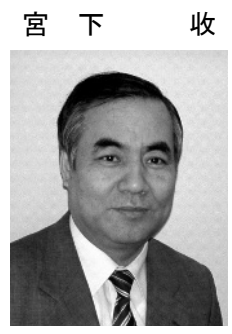

(正員) 1976 年, 東京電機大学大学院工学研 究科電気工学専攻修士課程修了。1977 年, 東京 電機大学工学部電気工学科助手。1985 年, 同講 師。1986 年, 理工学部応用電子工学科 (現, 電 子情報工学科）講師となり，現在教授。1988 年, Vrije Universiteit Brussel 研究員 (1 年間)。 工学博士。電気機器, パワーエレクトロニクス, メカトロニクス, 福祉工学に関する研究・教育 に従事。IEEE, EPE，ヒューマンインタフェース学会等の会員。 